Araştırma Makalesi - Research Article

\title{
Yaşlıların Uzun Dönemli Bakım Hizmetleri Yoluyla Sosyal İçermesi ve Eşiktelik Yaklaşımı
}

\section{Social Inclusion of Older Adults through Long Term Care Services and the Approach of Liminality}

\author{
Doğa Başar SARIIPPEK* \\ (iD) 0000-0002-3525-5199 \\ Emine Elif AYHAN** \\ (iD) 0000-0001-6692-0633
}

\section{ÖZ}

Dünya nüfusu hızla yaşlanmaktadır. Özellikle gelişmekte olan ülkelerde 65 yaş ve üzeri bireylerin toplam nüfus içinde hem sayı hem de oran olarak ağırlığının dikkat çekici şekilde artmakta olduğu yaygın kabul görmektedir. Yaşlanma ile ortaya çıkan bedensel ve bilișsel aksaklıklar kișilerin, üretkenliklerini yitirmelerine hatta gündelik yaşam aktivitelerini kendi kendilerine yerine getirememelerine neden olur. Bir anlamda yaşlanma ile kişiler, mevcut kimliklerinden ve toplumdaki rollerinden kopmaktadır. $\mathrm{Bu}$ dönemin belirgin bir özelliği toplumdan dışlanmadır. Üreticiliğini kaybederek, tüketici konumuna geçen ve başkalarının bakım desteğine ihtiyaç duyan yaşlıların pek çok bakım işi uzun dönemli bakım sistemi içinde yer aldığından, bu sistem yaşlıların sosyal içermelerine katkı sağlamaktadır. Bu çalışmada, yaşlanmanın ekolojik boyutuna değinilerek, yaşlı bireylerin kapasiteleri ile kendini gerçekleștirme ilișkisi üzerine durulmuştur. Ayrıca kişilerin yaşlanmadan dolayı bağımsız yaşamdan ayrılmaları ile yeni kimlik ve rollerini toplumun kabul etmesi arasında geçen zaman eşiktelik yaklaşımı (liminality) ile bağdaşlaştırılarak, yaşanan sosyal izolasyon sorununun uzun dönemli bakım hizmetleri uygulamalarıyla giderilebileceğinin ortaya konulması amaçlanmaktadır. $\mathrm{Bu}$ çerçevede makalede uzun dönemli bakım hizmetleri, sosyal içerme, yaşlanma ve yaşlı bağımlılığ kendini gerçekleştirme yaklaşımları ile birlikte ele alınarak, uzun dönemli bakım hizmetlerinin sosyal içermeye nasıl katkıda bulunduğuna yer verilmiştir.

Anahtar Sözcükler: Uzun dönemli bakım hizmetleri, yaşlanma, sosyal içerme, eşiktelik yaklaşımı, kendini gerçekleştirme
Sosyal Güvenlik Dergisi / Journal of Social Security

Sayfa Aralığı: 55-68 / Pages: 55-68

OI: 10.32331/sgd.952537

Önerilen atıf şekli: Sariipek, D.B. ve Ayhan, E. E. (2021). Yaşlıların Uzun Dönemli Bakım Hizmetleri Yoluyla Sosyal İçermesi ve Eşiktelik Yaklaşımı. Sosyal Güvenlik Dergisi (Journal of Social Security). 11(1). 55-68

• Geliş Tarihi/Received: 02/12/2020 • Güncelleme Tarihi/Revised: 14/05/2021 • Kabul Tarihi/Accepted: 14/06/2021

\footnotetext{
* Doç.Dr., Kocaeli Üniversitesi, İktisadi ve İdari Bilimler Fakültesi, Çalışma Ekonomisi ve Endüstri İlişkileri Bölümü, sariipek@kocaeli.edu.tr

** Doktora Öğrencisi, Kocaeli Üniversitesi, Sosyal Bilimler Enstitüsü, Yoksulluk Çalışmaları Programı, elifayhan93@gmail.com
} 


\section{GíRiş}

Nüfusun yaşlanması küresel bir fenomendir. Kalkınmışlık seviyesi ilerledikçe dünyadaki hemen her ülkede yaşlı nüfus oranında artış yaşandığı bilinmektedir. 2019 yılında dünya genelinde 65 yaş ve üstü 703 milyon kişi varken, bu sayının 2050 yılında ikiye katlanarak 1,5 milyara çıkması beklenmektedir. Oransal olarak ise 1990 yılında \%6 olan 65 yaş ve üstü nüfusun payının, 2050 yılına kadar \%16'ya çıkacağı tahmin edilmektedir. Böylece dünyadaki her 6 kişiden 1'inin 65 yaş ve üzerinde olacağı söylenebilir (United Nations, 2019: 1).

Uzun dönemli bakım, zihinsel ve/veya fiziksel kapasite kaybına sahip olan veya bu risk altında olan kişilerin, günlük temel ihtiyaçlarının karşılanmasını sağlayan hizmetlerdir. Fiziksel ve psikolojik olarak sağlığın bozulmasının en önemli sonuçlarından biri sosyal izolasyondur. Yaşlıların ise toplumda, sağlık bakımından en dezavantajlı konuma sahip grubu oluşturdukları söylenebilir. Çünkü yaşlanma, bir organizmanın biyolojik ve mental fonksiyonlarının uyum sağlama yeteneğinde meydana gelen düşüşlerdir. Fiziksel ve bilişsel sistemde yaşanan bozukluklar yaşlanmanın birey üzerinde meydana getirdiği en önemli değişikliklerdir. $\mathrm{Bu}$ değişiklikler özellikle bireylerin sosyal hayata katılımlarını engellediğinden sosyal izolasyon sorununu doğurmaktadır. Toplum içerisinde bir grubun sosyal izolasyona maruz kalması ise başta yoksulluk olmak üzere pek çok toplumsal soruna yol açabilir. Bu nedenle mal ve hizmetler ile sosyoekonomik güç ve kontrol kaynaklarına tüm bireylerin adil erişimine özel önem verilerek, bireylerin ve grupların toplumun imkân ve faydalarından tam olarak yararlanma ve katılma yeteneğini baskı altına alan yapısal engellere bir yanıt olarak tanımlanabilen sosyal içerme, özellikle toplumsal refahı sağlamak için olmazsa olmaz bir tedbirler bütünüdür.

$\mathrm{Bu}$ arka plan 1şı̆̆ında çalışmanın amacı, yaşlılıktan dolayı meydana gelen kapasite kayıplarının, profesyonel olan veya olmayan birinin hizmetleriyle karşılanmasını içeren uzun dönemli bakım sisteminin yaşlıların sosyal içermesinde önemli rol oynayacağını ortaya koymaktır. Uzun dönemli bakım genellikle yaşlı nüfusla ilgili olarak düşünülür. Çünkü hem kurumsal bakım hizmetleri hem de insanların kendi evlerinde sağlanan hizmetler özellikle 65 yaş ve üzerinde olanların ihtiyaçlarına yoğunlaşmaktadır. Dolayısıyla bu çalışmanın odak noktası, bakım gereksinimi olup, kendilerini finanse etme olasılığı en düşük nüfus grubu olan 65 yaş ve üstü nüfustur. Bu bilgiler ile birlikte çalışmanın birinci bölümü kavramsal bir çerçeve çizmeye yönelik olacaktır. İkinci bölümde uzun dönemli bakım hizmetlerine erişimin üç temel türü değerlendirilecektir. Son bölümde ise yaşlılar için eşiktelik yaklaşımı ve kendini gerçekleştirme kavramı değerlendirilerek, dünyadaki yaşı bağımlılığı verileri üzerinde durulacaktır.

\section{I- KAVRAMSAL ÇERÇEVE}

Yaşlanma hali ile birlikte sosyal dışlanma ve uzun dönemli bakım konularını geniş bir perspektiften ele almak mümkündür. Bu çerçevede, aralarında kurulabilecek en doğrudan ilişki, yaşlanmanın çoğu durumda sosyal dışlanmaya yol açabildiği; uzun dönemli bakım hizmetlerinin ise diğer birçok faydasının yanında, bu süreci tersine çevirebilme potansiyeli taşıdığı iddiasına dayanmaktadır. Dolayısıyla çalışmanın bu bölümünde, söz konusu kavramlara ilişkin açıklamaları ve analizleri bu bakış açısıyla ele alınmıştır.

\section{A- Uzun Dönemli Bakım Sistemi}

Uzun dönemli bakım, fizyolojik, sosyolojik ve zihinsel açılardan işlevsel kalabilmek için uzun vadeli bağımlılığı olan her yaştan insan için bakım hizmetlerinin sağlanması anlamına gelir. Kavrama ilişkin en kapsamlı tanımlardan birini yapmış olan Dünya Sağlık Örgütüne göre uzun dönemli bakım hizmetleri sürekli devam eden içsel kapasite kaybıyla karşılaşan 
kişilerin temel hak ve özgürlükleriyle ve aynı zamanda insan onuru ile tutarlı işlevsel yetenek seviyesini koruyabilmelerini sağlamak için başkaları tarafından yürütülen faaliyetlerin genel adıdır (WHO, 2015: 127). OECD’ye göre ise, yaşam içerisinde uzun vadeli bir desteğe ihtiyaç duyan kişiler için bir dizi bakım hizmetinden oluşan uzun dönemli bakım; kronik hastalık, sakatlık, travma hali ve yaşlılık durumuna ilişkin olgulara yönelik hizmetleri içermekte ve kişinin sağlık durumunu koruyarak, mevcut durumu daha katlanılabilir hale getirmeyi amaçlamaktadır (OECD, 2020: 6).

Kişiler, günlük yaşam aktiviteleri ve günlük yaşamın araçsal aktiviteleri olarak gruplandırılan ihtiyaçlarını bağımsız olarak yerine getiremedikleri zaman uzun dönemli bakım hizmetlerine gereksinim duyarlar. Genellikle yaşlılardan oluşan başkasının bakımına muhtaç kişiler banyo yapma, beslenme, giyinme ve yataktan inip çıkma gibi temel günlük görevler olan günlük yaşam aktivitelerini gerçekleştirmek ve sınırlı kapasiteyi telafi etmek için tasarlanmış kişisel bakım hizmetlerine ihtiyaç duymaktadır. Günlük yaşamın araçsal aktiviteleri ise alışveriş yapmak, temizlik yapmak, yemek hazırlamak, telefon gibi eylemleri içermektedir (ILO ve OECD, 2019: 2). Uzun dönemli bakım, sağlık ve sosyal sistemlerin ayrılmaz bir parçasıdır. Resmi olmayan bakıcılar (aile, arkadaşlar ve komşular), profesyoneller ve yardımcılar (sağlık, sosyal ve diğer çalışanlar) dahil olmak üzere kayıtlı ve kayıt dışı çalışanlar ile gönüllüler tarafından, bakım ihtiyacı duyan bireyler için gerçekleştirilen faaliyetleri içerir (Colombo, 2012: 26).

Önümüzdeki yıllarda uzun dönemli bakım hizmetlerinin gelişimini pek çok faktörün etkileyeceği öngörülmektedir. Bu faktörler arasında bebek patlaması kuşağının (babyboomer generation) yaşlanması, kişisel tercihlerin ve verilen bakım kalitesinin önem kazanması, teknolojinin yenilenmesi, bunama için yeni tedavi arayışı, finansman konuları, bakım hizmeti verecek işgücü düzenlemeleri bulunmaktadır. Şimdiki eğilim ve olası yeniliklere ait çıkarımlar Tablo 1'de yer almaktadır.

Tablo 1. Uzun Dönemli Bakımın Geleceğini Şekillendiren Kilit Güçler

\begin{tabular}{|c|c|}
\hline Şimdiki E ğilim & Olası Çıkarımlar \\
\hline Nüfus patlaması kuşağının yaşlanması & $\begin{array}{l}\text { Bakım hizmetlerinde deneyim ve çeşitliliğin artacağı } \\
\text { beklenmektedir. }\end{array}$ \\
\hline Kişisel seçim ve kişi merkezli bakıma ilginin artması & Bakımın tüm yönlerinde seçme hakkı artacaktır. \\
\hline Bakım kalitesinin vurgulanması & $\begin{array}{l}\text { Hizmet alıcılarının hizmetleri derecelendirmeleri ile } \\
\text { kalite gelişiminin giderek daha fazla artacağı } \\
\text { beklenmektedir. }\end{array}$ \\
\hline Teknolojik yenilik & $\begin{array}{l}\text { Robotlar, akıllı bakım evleri, elektronik sağlık izleme } \\
\text { ve iletişim araçlarında meydana gelecek yeniliklerin } \\
\text { bakıcıra da bağımlılığı azaltacağı öngörülmektedir. }\end{array}$ \\
\hline Bunama için yeni tedavi arayışı & $\begin{array}{l}\text { Bunama için yeni tedavilerin geliştirilmesi, uzun } \\
\text { dönemli bakım ihtiyacının ve biçiminin ana } \\
\text { belirleyicileri olacaktır. }\end{array}$ \\
\hline Maliyetleri kontrol altına almak & $\begin{array}{l}\text { Hem evde hem de kurumda uzun dönemli bakım } \\
\text { hizmetleri arasında hesap verebilirliğin artmasının } \\
\text { yanı sıra muafiyetlerin de artması beklenmektedir. }\end{array}$ \\
\hline İşgücü ihtiyaçları ve eksiklikleri & $\begin{array}{l}\text { Göçmenlik yasaları, yabancı işçilerin hemşirelik } \\
\text { asistanı ve evde sağlık bakımı yardımcıları olarak } \\
\text { hizmet etmesine izin verecek şekilde değişebilir. }\end{array}$ \\
\hline
\end{tabular}




\section{B- Sosyal İçerme}

Sosyal içerme, çok boyutlu ve dinamik bir olgudur. Aynı anda sosyal, kültürel, ekonomik ve politik alanları kapsar. İnsanları aynı zaman içerisinde farklı şekillerde ve farklı derecelerde etkilemektedir. Sosyal içerme mal ve hizmetlere erişimde eşitliği sağlamak, tüm bireylerin toplumlarına yapıcı ve verimli bir şekilde katılmalarına yardımcı olmak ve sosyokültürel ve ekonomik yaşama katkılarını teşvik etmek amacıyla bir dizi olumlu eylemi içermektedir. Aynı zamanda, her türlü ayrımcılığın farkında olmayı ve bunlara meydan okumayı da kapsamaktadır (O’Donnell, O’Donovan ve Elmusharaf, 2018: 2). Bu geniş bakış açısına göre sosyal içerme, toplum içinde dezavantajlı gruplara dahil olan bireylerin toplumda yer alma yeteneklerini, fırsatlarını ve haysiyetlerini geliştirme süreci olarak değerlendirilmelidir. Kısacası, sosyal içerme ekonomik, sosyal ve kültürel yaşama tam olarak katılma yeteneğidir.

Özü itibariyle sosyal içerme sahip olma, sevilme, sayılma/saygı duyulma/takdir edilme ve var olma anlamlarının bir bileşimidir. Sahip olmak, kültürel, ekonomik ve fiziksel araçlara erişimi ifade ederken, sevilme ve sayılma ise sosyal bağların mevcudiyetini yansıtmaktadır. Son olarak var olmak ise vatandaşlık hakları ve çalışma hayatına katılım gibi kendini gerçekleştirme hali ile ilgili bir duruma işaret etmektedir (Bengs, Hägglund ve WiklundEngblom, 2018: 11).

Sosyal içermeye yönelik politikalar özellikle yaşlı bireyler için çeşitli faydalar sağlamaktadır. $\mathrm{Bu}$ faydalar eşitsizlik ve yetkisizlikten ziyade bağımsızlığı teşvik eden sosyal alışverişler, sosyal kimliği destekleyen sosyal bütünleşme, toplumdaki üyeler tarafindan tanınma ve anlamlı sosyal etkileşim olarak belirtilebilir (Scharlach ve Lehning, 2013: 113). Buradan da anlaşılacağı üzere, sosyal içerme başlı başına bir sonuç olabileceği gibi başka sonuçların nedeni ve temeli de olabilir. Daha açık ifade etmek gerekirse, sosyal içerme politikalarının güçlü ve etkili uygulandığı ülkeler genellikle insan onuruna yakışır yaşam biçiminin yaygın olduğu ve kalkınmışlık düzeyinin yüksek olduğu toplumlardır. Nitekim bu ilişkiden hareketle Dünya Bankası dezavantajlı grupların toplum içindeki durumlarına ilişkin olarak "sosyal içerme değeri" adı altında bir endeks geliştirmiş ve bölgelerin buna göre kıyaslamasını yapmiştır.

Şekil 1. Sosyal İçerme Değeri 2018

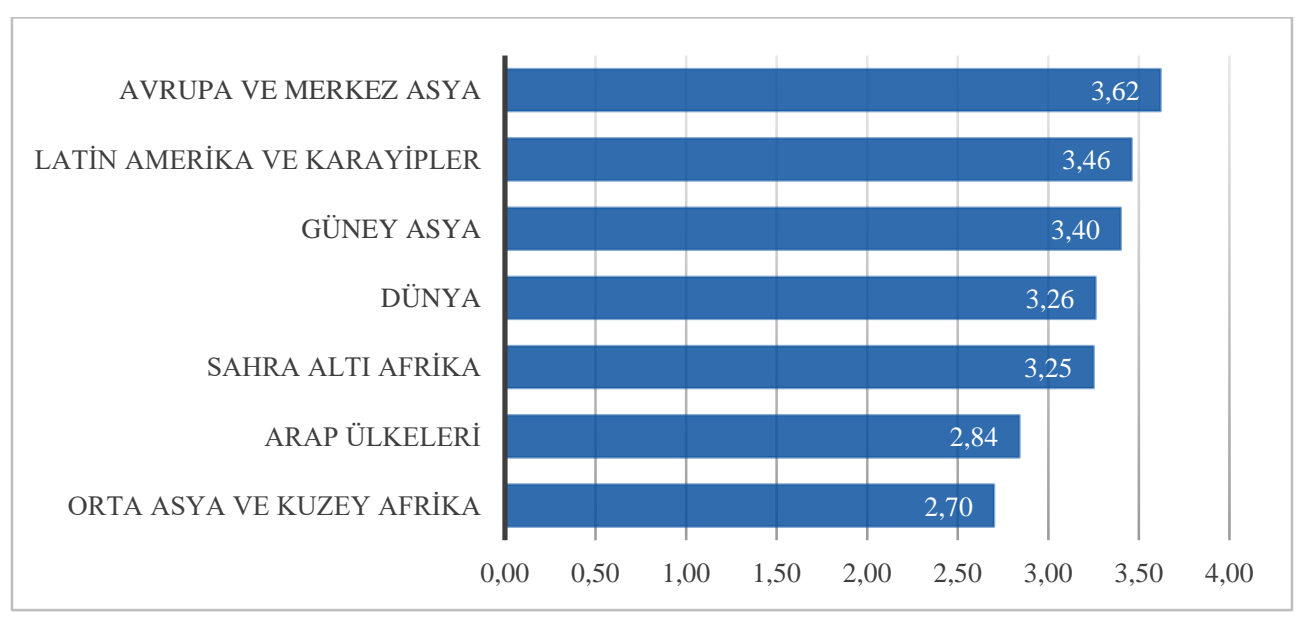

Kaynak: (World Bank, 2020) 
Sosyal içerme değeri 1 ile 6 arasında belirlenmekte ve 1 en düşük, 6 ise en yüksek sosyal içerme düzeyini temsil etmektedir. Şekil 1'e göre, sosyal içermenin en az olduğu ülkeler; Orta Asya ve Kuzey Afrika bölgesinde bulunurken, en fazla olduğu ülkeler; Avrupa ve Merkez Asya'dadır. Dünya ortalaması oranı ise 3.26'dır ve bu oranın 6'dan oldukça düşük olduğu söylenebilir. Sosyal içermenin az olması, sosyal izolasyonun olması anlamına gelebilmektedir. Buradan da tüm dünyada sosyal içermenin yetersiz olduğu ve sosyal içermeyi sağlayacak politikalara ihtiyaç duyulduğu sonucu çıkarılabilir.

\section{C- Yaşlanma}

Yaşlanma, insan hayatının evrensel bir özelliğidir. Kişinin vücut işlevlerinde azalma, sistem ve organlarında çeşitli değişikliklerin yaşandığı olgunluk döneminden sonraki yaşam aşaması olarak tanımlanabilir (Dziechciaż ve Filip, 2014: 835). Yaşlanma; biyoloji, ekonomi, kültür, sosyal yapılar, çevre ve tarih gibi alanları içerdiğinden tek bir yönden ifade etmek oldukça güçtür. Bundan dolayı geriatri ve sosyal hizmet, sosyal politika ve sağlık politikası, geleneksel insan bilimleri, işletme, teknoloji, etik, hukuk teorisi, beslenme, halk sağlığı, boş zaman çalışmaları gibi çeşitli disiplin perspektiflerinden incelenebilir (McMurtry ve Sasser, 2020: 30).

Yaşlanma, hayatın son evresini ifade eden ve kişiden kişiye göre değişiklik gösteren bir süreçtir. Meydana gelen tüm değişiklikler aynı anda gerçekleşmez ve yaşlanan kişinin yaşam koşullarına, yaşlandığ 1 yere, zamana, cinsiyetine veya sosyal durumuna bağlı olarak bireysel ve sosyal sonuçları farklılık gösterir. Yaşlanan insanlar arasında görülen değişikliklerin çoğu, hücrelerin, organların ve sistemlerin normal yaşlanma fizyolojik süreciyle ilişkilidir. Bununla birlikte, bazıları patolojilerden (kronik hastalıklar gibi) kaynaklanırken, diğerleri yaşam kaynaklarının aşırı kullanımı veya kullanılmamasının (yaşam tarzı ve kolektif yaşamın organizasyonu vb.) etkisidir (Woźniak, 2020: 51).

Şekil 2. Coğrafi Bölgelere Göre 65 Yaş ve Üstü Kişi Sayısı 2019-2050

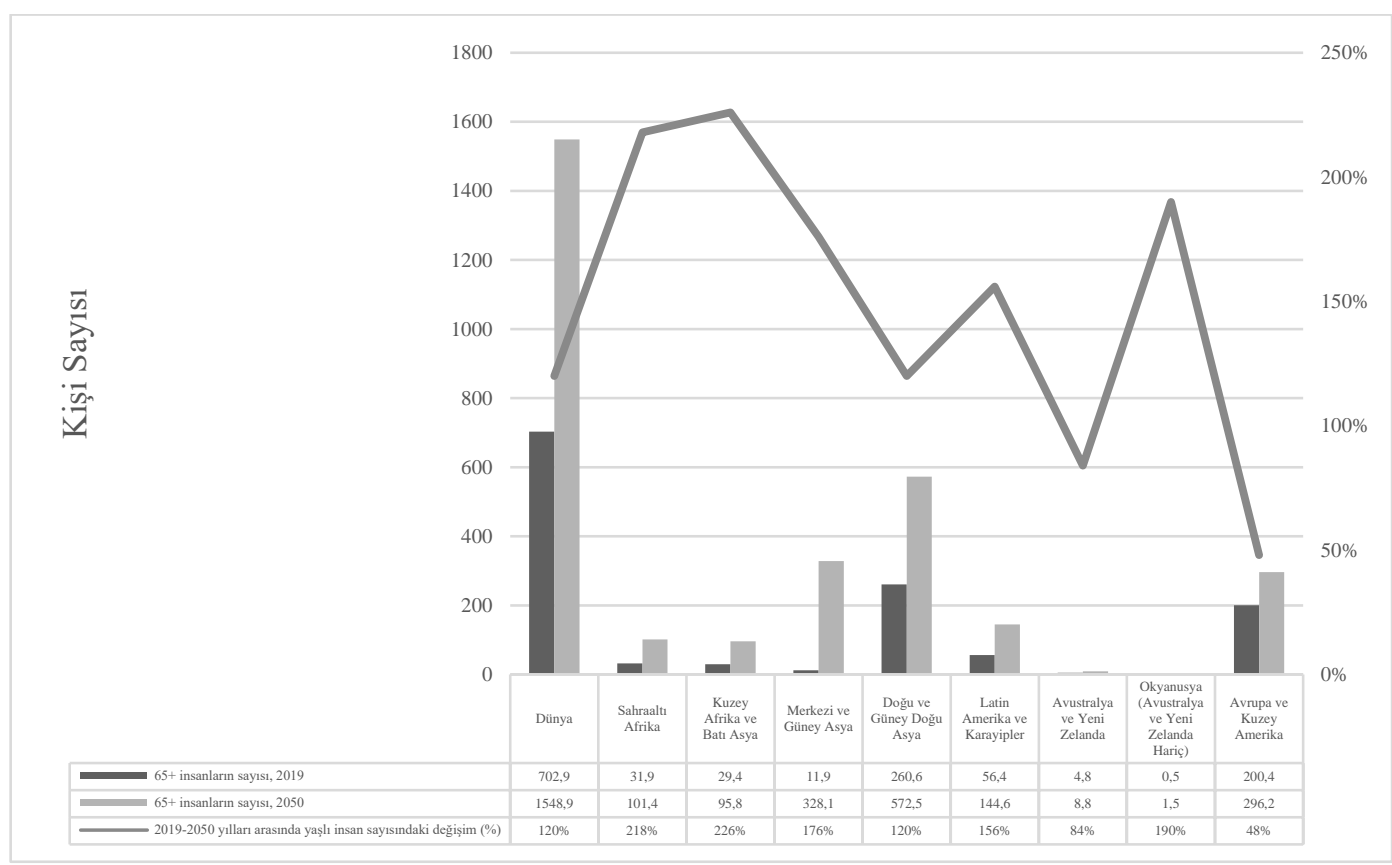

Kaynak: (United Nations, 2019:6) 
2019 yılında dünyada 65 yaş ve üstü 703 milyon yaşlı insan vardır. En yaşlı nüfus 2019 yılı itibariyle, 260 milyon ile Doğu ve Güneydoğu Asya bölgesindedir. Bu sayı1 200 milyon yaşlı nüfusuyla Avrupa ve Kuzey Amerika bölgesi takip etmektedir. Önümüzdeki otuz yıl içinde, küresel yaşlı sayısının iki kat (1,5 milyar) artacağı öngörülmektedir (Şekil 2). 20192050 yılları arasında ise yaşlı nüfusunun tüm bölgelerde artacağı tahmin edilmektedir. En büyük artış oranın Doğu ve Güneydoğu Asya bölgesinde olacağı Şekil 2'ye göre söylenebilir. Kuzey Afrika ve Batı Asya'da 2019'da 29 milyon olan yaşlı nüfusunun, 2050'de 96 milyona (\%226) ulaşarak, en hızlı artış oranını yakalaması beklenmektedir. Yaşlıların sayısındaki ikinci en hızlı artış, 2019'da 32 milyondan, 2050'de 101 milyona çıkması beklenen Sahra Altı Afrika'da (\%218) öngörülmektedir. Buna karşılık, öngörülen artış oranı Avustralya ve Yeni Zelanda'da \%84 ve Avrupa ve Kuzey Amerika'da \%48'dir ve nüfusu zaten dünyanın diğer bölgelerine göre önemli ölçüde daha yaşlı olduğu bilinen bu bölgelerde yaşlanma oranının nispeten az olacağı görülmektedir.

\section{D- Yaşlanma Türleri}

Yaşlanma olgusu çok yönlü ve çok boyutlu bir kavramdır. Bu nedenle çoğu yazar, kavrama çok farklı açılardan yaklaşmış ve sonuç olarak ortaya çok sayıda yaşlılık türü çıkmıştır. Yazındaki bu çeşitlilik karşısında bu çalışmada yaşlılık olgusuna yönelik çok yönlü bir bakış açısına sahip olan yaşam seyri teorisi referans alınmış ve yaşlanma türlerine bu teori ekseninde değinilmiştir. Yaşam seyri teorisi (Neugarten ve Hagestad, 1976), yaşlanma kavramının yalnızca kronolojik yönüne odaklanmak yerine; biyolojik, sosyal, psikolojik boyutlar başta olmak üzere birçok farklı boyutu esas alarak yapılandırır. Yaşam seyri teorisi yaşlanma sürecinin sadece bireysel yönüne odaklanmayan çok yönlü bir bakış açısına sahip olduğundan bu çalışmada referans alınmış ve yaşlanma türlerine bu teori ekseninde değinilmiştir.

i) Kronolojik Yaşlanma: Kişilerin doğduğu takvim tarihine dayanan kronolojik yaş, sosyal yaşamda kritik bir unsurdur ve yaşlanma ile ilgili oluşturulan politikaları değerlendirmek ve tanımlamak için önemli bir araçtır (Sugahara, 2019: 45).

ii) Biyolojik Yaşlanma: Yaşa bağlı olarak; hücrelerin fizikokimya özelliklerinde, metabolizmada, doku ve organlarda meydana gelen yapısal ve fonksiyonel değişiklikler biyolojik yaşlanma olarak tanımlanır (Dziechciaż ve Filip, 2014: 836).

iii) Patolojik Yaşlanma: Biyolojik yaşlanmaya bağlı olarak ortaya çıkan semptomlardan farklı bir şekilde çeşitli hastalıklarla ilişkili olan yaşlanma yaklaşımıdır. Genel nörofizyolojik sistemlerdeki verimliliğin düşmesi bilişsel gerilemeye neden olmaktadır. Başka bir ifade ile yaşlandıkça ortaya çıkan hafıza gerilemesi, çevresel faktörlerin de etkisiyle patolojik yaşlanmaya neden olmaktadır (Craik, 2008: 343-344)

iv) Psikolojik Yaşlanma: Kişinin yaşlanmaya bağlı olarak, bilişsel kapasitesindeki düşüşün, davranışsal uyum yeteneğini etkilemesi psikolojik yaşlanma olarak ifade edilmektedir (Rook, Charles ve Heckhausen, 2011: 351). Yaşlı insanların sosyal içermesinin iyileştirilmesi özellikle akıl sağlığı açısından oldukça faydalıdır. Çünkü en çok yaşlı intihar oranları toplumdan dışlanan yaşlılarda görülmektedir (Yur`yev, Leppik, Tooding, Sisask, Varnik, Wu ve Varnik, 2010: 1341).

v) Sosyal Yaşlanma: Toplum tarafından bireye atfedilen statü ve rolün zaman içerisinde (bireyin yaşlanması) değişmesi, sosyolojik açıdan yaşlanmayı ifade eder (Charles ve Carstensen, 2010: 392). Böylece, yaşlanmanın etkisiyle fiziksel ve zihinsel güç kaybı yaşayan bireylerin toplumdan dişlanma ihtimalinin yüksek olduğu söylenebilir. 
vı) Ekonomik Yaşlanma: Kişinin yaşlanma sebebiyle uğradığı fizyolojik değişiklikler, kişiyi ekonomik açıdan da etkilemektedir. Bu etki genellikle gelir düzeyinin azalması ve bunun sonucunda başkasına bağımlılığın artması ve hayat standartlarının düşmesi olarak tanımlanabilir (Kudo, Mutisya ve Nagao, 2015: 950).

\section{II- YAŞLILARIN UZUN DÖNEMLİ BAKIM HIZMETINE ERIŞ̧IMI}

Yaşlı bireyler, ücretli veya gönüllü olarak çalışma hayatına hem fiziksel hem de sosyal nedenlerle daha az katılırlar. $\mathrm{Bu}$ durumda herhangi bir güvencesi olmayan yaşlıların yoksullukla karşılaşması kaçınılmazdır. Yoksullukla birlikte, ulaşım engelleri, düşük hareketlilik (Rosso, Taylor, Tabb, Michael, 2013) görme, duyma gibi yetilerin zayıflaması (Wang, Rousseau, Boisjoly, Schmaltz, Kergoat, Moghadaszadeh, Djafari ve Freeman, 2012) gibi özellikler yaşlıların topluma katılım seviyelerini düşürerek, sosyal izolasyon riskini arttırmaktadır. Temel ihtiyaçların karşılanması, değer verilmesi ve saygı duyulması sosyal olarak kapsayıcı bir toplumdaki tüm insanlar için kritik faktörlerdir. Uzun dönemli bakım hizmetleri bu kritik faktörleri tek çatı altında toplayarak, yaşlıların sosyal içermesini sağlamaktadır.

Uzun dönemli bakım hizmetleri kamu, özel ve kâr amacı gütmeyen hizmet sağlayıcıları tarafından ayrı ayrı veya bir arada verilebilir (Zigante ve King, 2019: 7). Bu hizmet sağlayıcıları ülkelerin sağlık ve sosyal hizmet sistemlerinde yer almaktadır. Genellikle karmaşık uzun dönemli bakım ihtiyaçları olan bireylere destek verilmesinde görev alan farklı aktörlerin karışımı, sunulan hizmetlerin kalitesinin gözetilmesini sağlamada güçlükler yaratmaktadır (Langins, Steffler, Huber, Permanand, Jakab ve Melitta, 2020: 4). Bu nedenle hizmete erişim oldukça karmaşıktır. Ancak uzun dönemli bakım hizmetleri kurumsal tabanlı hizmetler (resmi), gayri resmi hizmetler ve topluma dayalı hizmetler olarak üç ana başlıkta ele alınabilir.

\section{A- Gayri Resmi Uzun Dönemli Bakım Hizmetleri (Enformel Bakım)}

Tüm kültürlerde ev; sıcaklık, istikrar, samimiyet, güvenlik ve özerklik olgularıyla birlikte anılmaktadır. Bu nedenle yaşamsal aktivitelerini yerine getiremeyen bireylere refah, rahatlık ve güvenliğin en iyi şekilde sağlanarak, destek ve bakım hizmeti verilecek yerin ev olduğu herkesçe kabul edilen bir gerçektir (Barrett, Hale, Gauld, 2012: 362). Böylece gayri resmi uzun dönemli bakım, insanların kendi ev ortamında yaşamalarını sağlayan hizmetlere atıfta bulunarak düşünülebilir.

Gayri resmi uzun dönemli bakım, herhangi bir ücret ödemesi yapılmayan aile üyeleri, arkadaşlar, gönüllüler ile özel olarak ișe alınmıș bakıcılara resmi olmayan yollarla ücret ödemesi yoluyla sağlanır (Boerma ve Genet, 2012: 9). Bu nedenle enformel bakım olarak adlandırılabilmektedir. Dolayısıyla gayri resmi uzun dönemli bakım hizmetleri, devlet düzenlemeleriyle ilişkisiz olarak sağlanan bakım hizmetlerini kapsar. Ev ortamında sağlanan bu hizmetler örgütlü olmadığından, hacmini ölçmek oldukça zordur.

\section{B- Topluma Dayalı Uzun Dönemli Bakım Hizmetleri}

Topluma dayalı hizmetler, bakım ihtiyaçlarının evde ve yaşanılan çevrede karşılandığı bakım işlerinden oluşur (Costa-Font ve Courbage, 2012: 195). Bu hizmetlerin amacı, bakım hizmeti talep edenlere uygun bir düzeyde bakım sunarak, bireyleri ev ortamlarında tutmaktır. Topluma dayalı uzun dönemli bakım hizmeti alıcıları, evde ve kurumsal bakım alıcılarına göre daha genç, yemek ve tuvalet ihtiyaçları için daha az bağımlı, aynı anda birden fazla hastalığın görülme ihtimalinin düşük olduğu profiller olarak nitelendirilebilir (Weissert, 1985: 425). 
Topluma dayalı bakım hizmetleri yelpazesi içerisinde fiziksel, zihinsel, sosyal, ekonomik ve güvenlik ihtiyaçları bulunmaktadır. Topluma dayalı bakım hizmeti alıcılarının ihtiyaçları, ikamet ettikleri bölgenin yerel yönetimleri tarafından değerlendirilir. Merkezi yönetimin dışında yerel yönetimler, yerel bir toplumun ortak ihtiyaçlarını gidermek üzere kurulan, demokratik ve özerk bir yönetim sistemidir (Tortop, Aykaç, Yayman, Özer, 2006: 2). Yerel yönetimler, hizmet sağlayıcılara finansman akışlarını düzenleyen kurallar da dahil olmak üzere, bakım hizmeti sistemi için kendi politikasını tasarlamakta serbesttir (Lau, Scandrett, Jarzebowski, Holman ve Emanuel,2007: 831). Evde sağlık bakımı ve yemek dağıtımı ile yetişkin gündüz bakımı ve yaşlı merkezlerinde olduğu gibi ayakta tedavi ve bakım hizmetleri topluma dayalı uzun dönemli bakım hizmetleri içerisinde yer almaktadır (Pardasani, 2010: 50).

\section{C- Kurumsal Tabanlı Uzun Dönemli Bakım Hizmetleri (Resmi/Formel Bakım)}

Kurumsal tabanlı uzun dönemli bakım, evde bakım hizmetlerinin artık bir seçenek olmadığg durumlarda bakım ihtiyacı duyan kişilere, kurumsal bir ortamda, yemek yeme ve yıkanma gibi temel günlük aktivitelerdeki yardımdan, iş veya sosyalleşme gibi yaşamın her alanına katılmaya kadar uzanan hizmetlerdir (Charlesworth, Firth, Fisher, Gershlick, Gray, Roberts, Starling, Thorlby ve Watt, 2017: 3). Kurumsal tabanlı uzun dönemli bakım, belirli bir süre boyunca bakım sağlama görevine odaklı ve bu görevde gerekli eğitimleri alarak uzmanlaşmış ve genellikle bir ücret karşılığı çalışanlar tarafından sağlanan hizmetler bütünüdür. Bakım bağımlılığı olan kişiler için bir dizi bakım işlerini kurumsal olarak organize etmek, temel hedef olarak belirlenmiştir (Blieszner ve Bedford, 1996: 462-463).

Yaşlı bakımı, çocuk yetiştirme ve çocuk bakımı, engelli bakımı, sosyal hizmet ve eğitim gibi faaliyetler kurumsal uzun dönemli bakım kapsamı içerisindedir (Folbre, 2006: 2). Ülkeden ülkeye farklı isimler taşıyan kurumsal tabanlı hizmetler türleri oldukça karmaşıktır. Bunun nedeni ülkelerin sosyal, kültürel ve ekonomik farklılıklarıdır. Ancak kabaca kurumsal tabanlı uzun dönemli bakım hizmetlerini; huzurevleri, bağımsız yaşlı konutları, kişisel bakım konutları, destekleyici yaşam konutları ve nitelikli bakım tesisleri olarak sınıflandırmak mümkündür (Singh, 2014).

\section{III- YAŞLILARIN UZUN DÖNEMLI BAKIM HIZMETLERIYLE SOSYAL İÇERMESINE YÖNELIKK YAKLAŞIMLAR}

Yaşlanmanın artması, çok boyutlu yoksulluk sorununu doğurmaktadır. Çok boyutlu yoksulluk toplumu; sosyal, ekonomik ve kültürel açılardan olumsuz etkilemektedir. Sıklıkla gündeme gelen olumsuz sosyal ve ekonomik etkiler arasında emeklilik dönemi için daha yüksek tasarruf ve sermaye yatırımı yapabilme yetkinliğinin azalması, kronik ve dejeneratif hastalıkların artması, sağlık hizmetleri ve emekli aylıklarına yönelik hükümet harcamalarının yükselmesi yer almaktadır. Bu olumsuz etkiler değişen işgücü profili, yaşlanmaya bağlı hastalıklar ve bunun sonucunda desteğe ve bakıma bağımlılığın artmasıyla ilişkilidir. Yaşlıların toplumla bütünleştirilmesinin sağlanması için öncelikle onların yeni kimliklerinin toplum tarafından benimsenmesi ve ihtiyaçlarına yönelik hizmetlerin etkin biçimde uygulanması gerekmektedir.

\section{A- Eşiktelik Yaklaşımı (Liminality)}

Dezavantajlı bireylerin toplumdaki belirsiz statüsü, onların diğerlerinden ayrılmasının sonucu olarak sosyal izolasyon sorununu doğurmaktadır. Bireylerin yaşadığı zamansal ve mekânsal değişim için Arnold Van Gennep, 1909 yılında "Geçiş Törenleri (Rite of Passage)" isimli bir çalışma yapmıştır. Bu çalışmada yaşanan değişim, üç aşamalı bir süreç olarak tanımlanır (akt. Leibing, Guberman ve Wiles, 2016: 12). Bunlar; 
Yaşlıların Uzun Dönemli Bakım Hizmetleri Yoluyla Sosyal İçermesi ve Eşiktelik Yaklaşımı

1) Geçiş törenindeki bireylerin, statülerinden ve benliklerinden ayrıldıkları dönem,

2) Statülerinden ve benliklerinden ayrılan bireylerin henüz kendisiyle bütünleşmedikleri eşiktelik (liminality) dönemi ve

3) Bireylerin yeni bir statü kazandıkları toplumda kabul gördükleri dönemdir.

Gennep tarafından kabaca "ayırma, geçiş ve bütünleşme" şeklinde ifade edilebilecek bu üç aşamanın ikincisi, Victor Turner tarafından genişletilerek, sosyal bilimler alanına eşiktelik kavramı olarak kazandırılmıştır. Eşiktelik kavramı, mevcut yaşam alanının verimliliğinin düşmesi ve kişinin statüsünün belirsiz bir hâl aldığını ifade etmek için kullanılır (Turner, 1969). Bu nedenle eşiktelik kavramı; çelişkili duyguları, belirsiz kimliği ve toplumdan güçlü bir bağlantısızlık durumunu içerir. Bu hâl özellikle yaşlı bireyler için geçerlidir. Çünkü yaşlanmadan dolayı kapasite düşüklüğü yaşayan bireyler engelli biri miyim, yardım almaya hakkım var mı? gibi karmaşık duygular yaşayarak zamansal, mekânsal ve sosyal ilişkileri bakımından bir geçiş süreci ile karşılaşır (Barrett, Hale, Gauld, 2012: 366). Turner’a göre eşiktelik süreci, sosyal görünmezlik ve sınıflandırma eksikliğiyle ilişkilendirilir (akt. Leibing, Guberman ve Wiles, 2016: 12). Bu aşamada yaşlilar, kendi kendilerine yetemediklerinden, toplum tarafindan tam olarak anlaşılamazlar ve sosyal izolasyon sorunu ortaya çıkar. Yaşlıların bozulmuş sağlık durumları, fiziksel yeteneklerinin kaybı ve sosyal ilişkilerinin azalması bağımsız yaşamdan ayrılmalarını tetikler. Bu belirtiler ve davranışlar, aile üyelerinin bakım hizmeti vererek yaşlının günlük bakım işine katılmasına neden olur. Sağlık ve sosyal hizmet çalışanlarıyla yeni kurulan bağ ve aile üyeleriyle değişen etkileşimler, eski kimlikten ayrılığa işaret eden sosyal alışverişleri oluşturur (Barrett, Hale, Gauld, 2012: 365-366).

\section{B- Kendini Gerçekleştirme (Self-realization)}

Yaşlanma, tek tip olmasa bile en azından genel olarak karakterize edilebilen şekillerde kişileri değiştirir. Sağlığın azalması, hareketliliğin kısıtlanması, kariyerin durması ve bundan dolayı yararlı hissetmenin zorlaşması ile akranların ölümlerine şahit olma gibi durumlar hem yaşlılar hem de toplum için yaşlanmanın rahatlıkla kabul edilebilecek bir süreç olmadığını göstermektedir. Fakat yaşlanma doğanın bir gerçeği olduğundan derin ekoloji bağlamında da ele alınabilecek bir olgudur. Çünkü ekoloji, doğa ve insan arasındaki ilişkiyi anlamlandırmayı sağlayacak yeni bir felsefe olarak, kişilerin yeryüzünde var oluşunu, hayat tecrübelerini ve sezgilerini ekolojik bilinçlilikle doğaya dayandırır (Önder, 2003: 157).

Derin ekolojinin nihai ilkelerinden biri "kendini gerçekleştirme" dir. Bu bağlamda kendini gerçekleştirme, insan ve insan dışındaki tüm varlıkların, kendi yaşam tarzlarını göre hayatlarını idame ettirmelerini benimser (Önder, 2019: 1058-1059). İnsan özelinde ele alındığında ise kendini gerçekleştirme, kişinin en derin arzularına veya en değerli kapasitelerine ulaşma amacını gütmesi ve bu amaca başarılı bir şekilde ulaşmasını temsil edecek şekilde kendi içinde en güçlü veya en iyi olanı ortaya çıkararak, kendini tamamlama çabasıdır (Gewirth, 1998: 3). Başka bir ifadeyle kendini gerçekleştirme, insanların başarabileceği en iyi, en derin, en değerli vb. şeyleri temsil eden, üstün bir şekilde formüle edilmiş hayalleri hedefleyen bir kavram olarak düşünülebilir (Laceulle, 2018: 95).

Yaşlıların kalan ömürlerinin, yaşadıkları ömürlerinden az olduğu aşikârdır. Sırf bu yüzden kendini gerçekleştirme çabasından vazgeçmeleri, onları eksikleştirerek toplumdan dışlanmalarını kolaylaştıracak bir neden olarak ele alınabilir. Uzun dönemli bakım hizmetlerinin, kendi kendine yetemeyen yaşlı bir bireye -başta temel ihtiyaçları olmak üzerepek çok ihtiyacını karşılamasına yardım ettiğinden, kendini gerçekleştirme çabasına da katkıda bulunduğu söylenebilir. Böylece kişiler yaşlanmayla özdeşleşir ve kendini gerçekleştirme çabalarını uzun dönemli bakım hizmetleriyle sağlayarak sosyal içermelerine katkı sağlanmış olur. 


\section{C- Bağımsız Yaşamdan Ayrılma ve Yaşlı Bağımlılı̆̆ı}

Yaşlıların günlük yaşam aktivitelerini yerine getirememeleri, bağımsız yaşama yeteneklerine yönelik en büyük tehditlerden biridir. İşlevsel gerileme ve hareketlerin kısıtlanması sonucu kişisel gereksinimlerini karşılayamayan yaşlı bireyler, hayatlarını devam ettirebilmek için kimi zaman bir aile üyesine kimi zaman da profesyonel veya profesyonel olmayan bir bakıcıya bağımlı hale gelmektedir. Doğurganlığın azalması ve uzun ömürlülüğün artması, küresel olarak nüfusun yaşlanmasının temel itici güçleridir. Bu durumda 20-64 yaşları arasında olan 100 kişi başına, 65 yaş ve üzeri bireylerin sayısı olarak tanımlanan yaşlı bağımlılık oranı (OECD, 2015: 158) her geçen gün artmaktadır. Yaşlı bağımlılık oranına ilişkin veriler Tablo 2'de düzenlenmiştir.

Tablo 2. Uzun Dönemli Bakımın Geleceğini Şekillendiren Kilit Güçler

\begin{tabular}{|c|c|c|c|c|c|c|c|c|c|c|c|c|}
\hline \multicolumn{7}{|c|}{ Yaşlı bağımlılık oranı \% (65+/(15-64)) } & \multicolumn{6}{|c|}{ Çok yaşıı bağımlılık oranı \% $(80+/(15-64))$} \\
\hline Bölgeler & 1960 & 2000 & 2015 & 2070 & $\begin{array}{c}\text { Yüzde } \\
\text { puanı } \\
1960- \\
2015\end{array}$ & $\begin{array}{c}\text { Yüzde } \\
\text { puanı } \\
2015- \\
2070\end{array}$ & 1960 & 2000 & 2015 & 2070 & $\begin{array}{c}\text { Yüzde } \\
\text { puanı } \\
1960- \\
2015\end{array}$ & $\begin{array}{c}\text { Yüzde } \\
\text { puanı } \\
2015- \\
2070\end{array}$ \\
\hline Dünya & 8,6 & 10,9 & 12,6 & 30,5 & 4 & 17,8 & 1 & 1,9 & 2,6 & 9,9 & 1,6 & 7,3 \\
\hline Afrika & 5,7 & 6,2 & 6,2 & 13,5 & 0,6 & 7,3 & 0,5 & 0,7 & 0,8 & 2,7 & 0,4 & 1,8 \\
\hline Asya & 6,4 & 9,1 & 11,2 & 36,5 & 4,7 & 25,4 & 0,6 & 1,3 & 2 & 12,0 & 1,5 & 10 \\
\hline Çin & 6,5 & 10,1 & 13,3 & 53,3 & 6,8 & 39,9 & 0,3 & 1,5 & 2,3 & 22,1 & 1,9 & 19,8 \\
\hline Japonya & 8,8 & 24,9 & 42,7 & 69,6 & 33,9 & 27 & 1,1 & 5,4 & 12,4 & 35,8 & 11,4 & 23,3 \\
\hline Hindistan & 5,4 & 7,2 & 8,6 & 31 & 3,2 & 22,4 & 0,6 & 0,9 & 1,3 & 7,6 & 0,8 & 6,3 \\
\hline Avrupa & 13,6 & 21,8 & 26,4 & 49,4 & 12,8 & 23 & 2 & 4,3 & 7 & 21,5 & 5 & 14,4 \\
\hline Rusya & 9,6 & 18,0 & 19,4 & 34,5 & 9,8 & 15,1 & 1,3 & 2,9 & 4,5 & 14,1 & 3,2 & 9,6 \\
\hline AB & 15,2 & 23,4 & 29,2 & 54,2 & 14,1 & 25 & 2,3 & 5 & 8,2 & 24 & 5,9 & 15,9 \\
\hline $\begin{array}{l}\text { Latin } \\
\text { Amerika ve } \\
\text { Karayipler }\end{array}$ & 6,8 & 8,9 & 11,4 & 45 & 4,6 & 33,6 & 0,8 & 1,6 & 2,4 & 16,4 & 1,7 & 13,9 \\
\hline $\begin{array}{l}\text { Kuzey } \\
\text { Amerika }\end{array}$ & 15 & 18,6 & 22,3 & 43,6 & 7,3 & 21,3 & 2,3 & 4,9 & 5,7 & 16,8 & 3,3 & 11,2 \\
\hline ABD & 15,2 & 18,7 & 22,1 & 43,1 & 7 & 20,9 & 2,3 & 4,9 & 5,6 & 16,4 & 3,3 & 10,8 \\
\hline Okyanusya & 12,5 & 15,4 & 18,5 & 34,1 & 6 & 15,6 & 1,9 & 3,4 & 4,6 & 12,7 & 2,7 & 8,1 \\
\hline
\end{tabular}

Kaynak: (European Commission, 2018: 28)

Tablo 2'deki yaş yapısına bakıldığında, Avrupa'nın en yüksek yaşlı bağımlılık oranına sahip en eski kıta olduğu ve 2070 yılında da böyle kalacağı görülmektedir. Bununla birlikte, diğer kıtalarda da nüfusların dramatik bir şekilde yaşlanacağı ve yaşlı bağımlılık oranlarının artacağı tahmin edilmektedir. Ayrıca, Latin Amerika ve Karayipler' in 2015-2070 döneminde yaşlı bağımlılık oranında \%33,6 ile en yüksek artışı yaşayacağ 1 , Asya $(\% 25,4)$ ve Avrupa'nın (\%23) ise hemen arkasından geleceği anlaşılmaktadır. Demografik değişimin özellikle yaşlı bağımlılık oranını Çin ve Japonya'da sırasıyla 40 puan ve 27 puan arttıracağı öngörülmektedir. Çin ve Japonya'nın hemen ardından \%25 ile AB gelmektedir. 2015-2070 döneminde ise çok yaşlı bağımlı nüfus oranındaki en yüksek artışın Japonya'da $(\% 23,3)$ olacağ 1 , onu Çin $(\% 19,8)$ ve AB $(\% 15,9)$ ülkelerinin izleyeceği tahmin edilmektedir. Bu önemli demografik değişim tahminleri sonucunda, 2070 yılına kadar Japonya, AB ve Çin'in büyük ekonomiler arasında en yüksek yaşlı bağımlılık oranlarına sahip olacağı, bu ülkeleri 
Yaşlıların Uzun Dönemli Bakım Hizmetleri Yoluyla Sosyal İçermesi ve Eşiktelik Yaklaşımı

de ABD ve Hindistan'ın izleyeceği değerlendirilmektedir. Nüfuslarının yüksek olmasıyla da dikkat çeken bu ülkeler başta olmak üzere diğer ülkeler de kaçınılmaz olarak bağımlılık yükünü hafifletmek üzere sosyal politikalara ağırlık vermek zorunda kalacaktır.

\section{SONUÇ}

Yaşlanmaya ilişkin ölçütler ve kavramlar, yaşlıların hayat standartlarını ve toplumdan beklentilerini, üretkenliklerini ve topluma katkılarını, sosyal koruma ve sağlık bakımı ihtiyaçlarını değerlendirmek için önemli çıkarımlara sahiptir. Çünkü yaşlanmaya geçiş aşamasını saptamak oldukça zordur. Yaşlılık statüsü kazanan bireyi toplumun kabul etmesi ve yeni statüsüne uygun koşulları sağlaması zaman alacağından, sosyal izolasyon sorunu ortaya çıkacaktır. Yaşlıların sosyal içermelerini sağlayacak en önemli hizmetler, uzun dönemli bakım hizmetleridir. Çünkü uzun dönemli bakım hizmetleri geniş bakım hizmetleri yelpazesine sahip, hizmetlere ulaşmak için pek çok yolu olan ve profesyoneller tarafindan üstlenilen bakım sistemleridir. Böylece uzun dönemli bakım yoluyla yaşlıların sosyal içermesi aşağıdaki yollarla sağlanabilmektedir.

- Uzun dönemli bakım hizmetleri, yaşlıların kapasite kayıplarını telafi ederek, sosyal hayata katılımı teşvik eder ve bu sayede toplumun refahı ve ruh sağlığı güçlendirilebilir. $\mathrm{Bu}$, başarılı ve güçlü topluluklar için bir temel olarak kabul edilebilir.

- Günlük yaşamın temel faaliyetlerini yürütmek için yardım sağlanmasıyla, bireyin yaşam ortamında, günlük yaşamın organizasyonunda ve sosyal ağlarda sürekliliği sağlayabileceği söylenebilir.

- Yaşlıların kapasite kayıpları bakım hizmetleri ile telafi edilerek, toplumdaki statülerinin düşmemesi sağlanacağından, daha yüksek ahlaki standartların tanınması ve onlara karşı duyulan dostane duygular, intihar ölümleriyle ters orantılı olacaktır.

- Hızla gelişen bilgi ve iletişim teknolojileri hem yararlı araçlar olarak kabul edilmekte hem de sosyal dışlanma için önemli bir neden olarak eleştirilmektedir. Bu eleştiriler özellikle yaşlı bireylerin, gelişen teknolojik araçlara uyum sağlayamamalarından kaynaklanmaktadır. GYAA içerisinde yer alan teknolojik araçlar, uzun dönemli bakım sayesinde yaşlıların hizmetine sunulmaktadır.

Yaşamın özellikle son dönemlerinde kaybedilen yetenekleri telafi etmek için kullanılan uzun dönemli bakım hizmetlerinin, yaşlıların topluma katılımları için oldukça önemli olduğu görülmektedir. Uzun dönemli bakım hizmetleri ile yaşlılara yaratılacak sosyal içermeyi teşvik edecek fiziksel ve sosyal ortamlar;

Süreklilik: Uzun süre devam edecek faaliyetlere ve ilgi alanlarına sürekli katılımın önünde engellerin olmamasi.

Telafi: Yaşa bağlı engellere rağmen temel sağlık ve sosyal ihtiyaçların karşılanması.

Sosyal Băglantı ve Katkı: Toplumdaki bireyler ile ilişkiler geliştirme ve sürdürme fursatları ile çevresinde etkiye sahip olmak.

Meydan Okumak: Yeni faaliyetlerin ve ilgi alanlarının teşvik edilmesi ile birlikte anılmaktadır. Uzun dönemli bakım hizmetlerinden yararlanmaya başlayan bir kişinin gelir kaynakları, tıbbi geçmişi ve hastalık teşhisleri, mevcut tedavileri, iletişim yeteneği, görme ve işitme duyuları, hareketliliği, kişisel bakım yeteneği ve bilişsel işlevsellik gibi yaşam aktivitelerini yerine getirme düzeyi artar. Aynı zamanda, topluma katılım ve uyum sağlama yeteneği de güçlendirilerek, yaşlıların sosyal içerme düzeyleri desteklenmiş olur. 


\section{Kaynakça}

Barrett, P., Hale, B. ve Gauld, R. (2012). Social Inclusion Through Ageing-In-Place With Care? Ageing and Society. 361.378.

Bengs, A., Hägglund, S. ve Wiklund-Engblom, A. (2018). Applying Experience Design to Facilitate Wellbeing and Social Inclusion of Older Adults. Interaction Design and Architecture(s) Journal. 11-30.

Blieszner, R. ve Bedford, V. (1996). Aging and the Family: Theory and Research. London: Praeger.

Boerma, W., \& Genet, N. (2012). Introduction and Background. E. N. Genet, W. Boerma, M. Kroneman, A. Hutchinson, \& R. B. Saltman içinde, Home Care across Europe; Current Structure and Future Challenges (s. 1-25). United Kingdom: World Health Organization.

Charles, S. ve Carstensen, L. L. (2010). Social and Emotional Aging. Annual Review of Psychology. 383-409.

Charlesworth, A., Firth, A., Fisher, R., Gershlick, B., Gray, H., Roberts, A. ve Watt, T. (2017). The Social Care Funding Gap: Implications for Local Health Care Reform. The Health Foundation.

Colombo, F. (2012). Typology of Public Coverage for Long-Term Care in OECD Countries. E. J. Costa-Font ve C. Courbage. Financing Long-Term Care in Europe Institutions. Markets and Models. 17.41. London: Palgrave Macmillan.

Costa-Font, J. ve Courbage, C. (2012). Financing Long-Term Care: New and Unresolved Questions. E. J. Costa-Font and C. Courbage. Financing Long-Term Care in Europe Institutions, Markets and Models. 3.16. London: Palgrave Macmillan.

Craik, F. I. (2008). Memory Changes in Normal and Pathological Aging. The Canadian Journal of Psychiatry. 53.6. 343. 345.

Dziechciaż, M. ve Filip, R. (2014). Biological Psychological and Social Determinants of Old Age: Bio-Psycho-Social Aspects of Human Aging. Annals of Agricultural and Environmental Medicine. 21.4. 835-838.

European Commission. (2018). The 2018 Ageing Report: Economic and Budgetary Projections for the EU Member States (20162070). Brussels: European Union.
Folbre, N. (2006). Demanding Quality: Worker/ Consumer Coalitions and 'high road' Strategies in the Care Sector. Politics and Society. 34.1. 1132.

Gewirth, A. (1998). Self-Fulfillment. Princeton. New Jersey: Princeton University Press.

ILO, OECD. (2019). New Job Opportunities in an Ageing Society. Tokyo, Japan: Paper Prepared for the 1st Meeting of the G20 Employment Working Group.

Kudo, S., Mutisya, E. ve Nagao, M. (2015). Population Aging: An Emerging Research Agenda for Sustainable Development. Social Sciences. 940-966.

Laceulle, H. (2018). Aging ve Self-Realization: Cultural Narratives about Later Life. Bielefeld: Transcript Verlag.

Langins, M., Steffler, J., Huber, M., Permanand, G. ve Jakab, M. (2020). Strengthening The Healty System Response to COVID-19. Copenhagen: World Health Organization.

Lau, D. T., Scandrett, K. G., Jarzebowski, M., Holman, K. ve Emanuel, L. (2007). HealthRelated Safety: A Framework to Address Barriers to Aging in Place. The Gerontologist. 47.6. 830-837.

Leibing, A., Guberman, N. ve Wiles, J. (2016). Liminal Homes: Older People. Loss of Capacities and the Present Future of Living Spaces. Journal of Aging Studies. 10-19.

McMurtry, A. ve Sasser, J. (2020). Interdisciplinary and Transdisciplinary Approaches to Ageing and Gerontology. M. Łuszczyńska. Researching Ageing Methodological Challenges and their Empirical Background. 70-93. Abingdon, Oxon; New York, NY.: Routledge.

Neugarten, B. L. ve Hagestad, G. (1976). Age and the Life Course. R. Edt. Binstock, and E. Shanas. Handbook of Aging and the Social Sciences. 35-55. New York: Van Nostrand Reinhold.

OECD (2015). Pensions at a Glance 2015: OECD and G20 Indicators. Paris: OECD Publishing.

OECD (2020). Long-term Care and Health Care Insurance in OECD and Other Countries. [http://www.oecd.org/fin/insurance/Long-TermCare-Health-Care-Insurance-in-OECD-and-otherCountries.htm.]. (Erişim: 25 Ekim 2020). 
O’Donnell, P., O’Donovan, D. ve Elmusharaf, K. (2018). Measuring Social Exclusion in Healthcare Settings: a Scoping Review. International Journal for Equity in Health. 1.16.

Önder, T. (2003). Ekoloji, Toplum ve Siyaset. Ankara: Odak Yayınevi.

Önder, T. (2019). Doğayla Sözleşme: EkoMerkezci Siyasetin İmkânı. Kent Araştırmaları Dergisi. 28(10). 1050.1068.

Pardasani, M. (2010). Senior Centers: Characteristics of Participants and Nonparticipants. Activities. Adaptation and Aging. 34.1. 48-70.

Rook, K. S., Charles, S. T. ve Heckhausen, J. (2011). Aging and Health. E. H. Friedman. The Oxford Handbook of Health Psychology. 347374. Oxford University Press.

Rosso, A. L., Taylor, J. A., Tabb, L. P. ve Michael, Y. L. (2013). Mobility, Disability and Social Engagement in Older Adults. Journal of Aging and Health. 25.4. 617-637.

Scharlach, A. E. ve Lehning, A. J. (2013). Ageing-Friendly Communities and Social Inclusion in the United States of America. Ageing \& Society. 110.136.

Singh, D. A. (2014). Effective Management of Long-Term Care Facilities. Burlington, MA: Jones \& Bartlett Learnings.

Sloane, P. D., Zimmerman, S. ve D’Souza, M. F. (2014). What Will Long-Term Care Be Like in 2040? North Carolina Medical Journal. 75.5. 326-330.

Sugahara, G. (2019). Urban Population Ageing and its Impact on Social Policy- Lessons from Oslo. Spring.

Tortop, N., Aykaç, B., Yayman, H. ve Özer, M. A. (2006). Mahalli İdareler. Ankara: Nobel Yayın Dağıtım.

Turner, V. (1969). The Ritual Process. Harmondsworth. UK: Penguin.

United Nations. (2019). World Population Ageing. New York: United Nations.

Wang, M. Y., Rousseau, J. B., Hélène, S., Heidi, K., MarieJeanne, Moghadaszadeh, S. ve Freeman, E. E. (2012). Activity Limitation due to a Fear of Falling in Older Adults with Eye Disease. Investigative Ophthalmology and Visual Science. 53.13. 7967-7972.
Weissert, W. G. (1985). Seven Reasons Why It Is So Difficult to Make Community-Based Long-Term Care Cost-Effective. Health Services Research. 423-433.

WHO (2015). World Report on Ageing and Health. Geneva: World Health Organization.

Woźniak, Z. (2020). Older Adults - Terra Incognita? M. Łuszczyńska. Researching Ageing Methodological Challenges and their Empirical Background. 51-69. Abingdon, Oxon; New York, NY.: Routledge.

World Bank (2020). World Development Indicators. DataBank: [https://databank.worldbank. org/reports.aspx? source $=2 \&$ series=IQ.CPA.SO CI.XQ\& country=\# ]. (Erişim: 20 Ekim 2020).

Yur`yev, A., Leppik, L., Tooding, L. M., Sisask, M., Varnik, P., Wu, J. ve Varnik, A. (2010). Social Inclusion Affects Elderly Suicide Mortality. International Psychogeriatrics. 13371343.

Zigante, V. ve King, D. (2019). Quality Assurance Practices in Long-Term Care in Europe Emerging Evidence on Care Market Management. Luxembourg: Publications Office of the European Union. 
